\title{
UPDATES IN INDIANA LAKE AND WATER LAW: SEPTEMBER 1, 2018 - AUguST 31, 2019
}

\author{
WILLIAM W. GOODEN* \\ OLIVIA A. HESS ${ }^{* *}$
}

\section{INTRODUCTION}

This paper summarizes several cases relating to Indiana lake and water law which were handed down between September 1, 2018, and August 31, 2019. First, we discuss two cases related to competing riparian rights. Next, this article focuses on a pair of cases concerning the regulation of certain lakefront property based on its classification as adjacent to or located within the boundaries of an Indiana public freshwater lake. Finally, we highlight another duo of cases which address various issues stemming from Notices of Violation issued under the Dam Safety Act.

But before jumping in, a brief refresher as to the importance of lake and water jurisprudence in Indiana is in order. In short, Indiana is among a relative few states in the nation that enjoys an abundance of natural (as opposed to manmade), glacially-formed, spring fed, freshwater lakes, upon which thousands of private and public properties sit. It may be well known that the northern one-third of Indiana is speckled with hundreds of natural lakes of all shapes and sizes. Many also know that Indiana is blessed with these beautiful natural creations due to the melting and retreat of the last glacier, the Wisconsin Glacier, somewhere around 15,000 years ago.

What may not be as well known is that Indiana has a robust substantive and procedural framework and body of law pertaining specifically to our natural lakes and to the related matters associated with the watersheds in which our lakes sit. This framework necessarily includes issues related to watercourses, dams, and the like.

The primary statutory and regulatory framework pertaining to lake and water law in Indiana is found in Indiana Code section 14-26-2 et seq. and 312 IAC 11 et seq. Indiana Code section 14-26-2, et seq., is known as the "Lakes Preservation Act." Fittingly, the Lakes Preservation Act contains some unusually rich and poetic language, not commonly found in the riveting prose that is the typical statutory construct. For example, Indiana Code section 14-26-2-5, titled "Public Rights," provides:

Sec. 5.

(a) As used in this section, "natural scenic beauty" means the natural condition as left by nature without manmade additions or alterations.

(b) As used in this section, "recreational purpose" means the following:

* Partner, Clark, Quinn, Moses, Scott \& Grahn, LLP in Indianapolis, Indiana; J.D., 1996, Indiana University School of Law - Indianapolis; B.S., 1992, Ball State University.

** Associate Attorney, Clark, Quinn, Moses, Scott \& Grahn, LLP in Indianapolis, Indiana; J.D., 2020, summa cum laude, Indiana University Robert H. McKinney School of Law; B.A., 2016, Indiana University-Purdue University Indianapolis. 
(1) Fishing.

(2) Boating.

(3) Swimming.

(4) The storage of water to maintain water levels.

(5) Any other purpose for which lakes are ordinarily used and adapted.

(c) The:

(1) natural resources and the natural scenic beauty of Indiana are a public right; and

(2) public of Indiana has a vested right in the following:

(A) The preservation, protection, and enjoyment of all the public freshwater lakes of Indiana in their present state.

(B) The use of the public freshwater lakes for recreational purposes.

(d) The state:

(1) has full power and control of all of the public freshwater lakes in Indiana both meandered and unmeandered; and

(2) holds and controls all public freshwater lakes in trust for the use of all of the citizens of Indiana for recreational purposes.

(e) A person owning land bordering a public freshwater lake does not have the exclusive right to the use of the waters of the lake or any part of the lake.

Where else would we find a definition of "natural scenic beauty" and the use of terms and phrases like "left by nature without manmade . . alteration" and "the public ... has a vested right in ... enjoyment of all the public freshwater lakes" than in these statutes that govern our natural treasures? But while these statutes and regulations make clear that the public freshwater lakes, which are listed specifically and enumerated in "Natural Resources Commission Information Bulletin \#61," are held in trust by the State for the benefit of the public, there are important intersecting and competing private property rights in our lakes.

As provided in 312 IAC 11-2-19, a "riparian owner" is defined as "the owner of land . . . bound by a lake." So, the owner of an Indiana "lake cottage," as we affectionately call them, is a riparian owner, where the parcel of land on which the cottage sits on and directly abuts the lake. This also applies, of course, even if the land is vacant. Lakefront property is valuable. With this background in mind, it is evident that legal disputes are commonly born of competing and intersecting riparian property ownership. Having provided this context, we move forward with our summary of recent developments in this historically and geographically significant area of Indiana law.

\section{RIPARIAN RIGHTS}

Indiana's Natural Resources Commission has adopted a rule defining a 
"riparian owner" to mean ". . . the owner of land . . . bound by a lake." "'Riparian rights' are vested property rights that arise out of ownership of land bounded or traversed by navigable water." "A riparian owner typically enjoys rights that include: '(1) access to navigable water; (2) the right to build a pier out of the line of navigability; (3) the right to accretions; and (4) the right to a reasonable use of the water for general purposes such as boating, domestic use, etc."' This section discusses two cases related to riparian rights in Indiana.

England v. Ball \& Arend considered a riparian rights dispute on Witmer Lake in LaGrange County. ${ }^{4}$ The Englands, riparian owners, alleged that their neighboring riparian owners', the Balls', temporary pier structure encroached on the Englands' riparian boundary zone. ${ }^{5}$ In order to adjudicate the issue, the common riparian boundary between Ball and the Englands needed to be determined. "Any method of apportionment applicable in establishing riparian zones must 'divide the total navigable waterfront in proportion to the length of the actual shorelines of each owner taken according to the general trend of the shore." $" 6$

The shoreline at issue in England was irregular due to its concave nature. ${ }^{7}$ The Natural Resources Commissions' non-rule policy document Information Bulletin $\# 56^{8}$ is an agency statement adopted in accordance with Indiana Code section 4-22-7-7. "Information Bulletin \#56, as its 'Fourth Principle', states ' $[w]$ here the shore is irregular, and it is impossible to run lines at right angles to the shore for a just apportionment, the lines forming the boundaries between riparian zones should be run to divide the total navigable waterfront in proportion to the length of the shores of each owner taken according to the general trend of the shore. . .." The Administrative Law Judge ("ALJ") in England determined that the riparian boundary line between the Englands and Ball was to be determined consistent with the Fourth Principle in Information Bulletin \#56. ${ }^{10}$ Additionally, consistent with other provisions in Information Bulletin \#56, the order of the ALJ established that a buffer zone must be maintained on either side of each common riparian boundary. ${ }^{11}$

1. 312 Ind. AdMin. Code 11-2-19 (2019).

2. 78 Am. Jur. 2d Waters $\S 33$ (2020).

3. England v. Ball \& Arend, 15 CADDNAR 77, 79 (2019) (quoting Parkison v. McCue, 831

N.E.2d 118, 128 (Ind. Ct. App. 2005)).

4. England, 15 CADDNAR at 77.

5. Id. at 79 .

6. Id. at 80 (quoting Nosek v. Stryker, 309 N.W.2d 868, 872 (Wis. Ct. App. 1981), cited favorably in Lukis v. Ray, 888 N.E.2d 325 (Ind. Ct. App. 2008)).

7. England, 15 CADDNAR at 80 .

8. Riparian Zones within Public Freshwater Lakes and Navigable Waters, Information Bulletin \#56 (Second Amendment), Indiana Register 20100331-IR-312100175NRA(Mar. 31, 2010) [hereinafter Information Bulletin \#56].

9. Id.

10. Id.

11. Id. ("Information Bulletin \#56, page 2 states, 'To assist with safe navigation, as well as 
Kiefer $v$. Diller similarly considered a dispute associated with the exercise of riparian rights. ${ }^{12}$ Specifically, Kiefer alleged that the Dillers "unlawfully placed a pier and moored a boat within the waters of Blue Lake in a manner that interferes with her exercise of riparian rights." ${ }^{\prime 3}$ Kiefer owned property, Lot 5, which shared a boundary with the shoreline of Blue Lake, thus making Kiefer a riparian owner. ${ }^{14}$ The Dillers owned property, Lot 47 , which did not share a boundary with the shoreline of Blue Lake. ${ }^{15}$ As such, the Dillers were not riparian owners. ${ }^{16}$ On a ten foot strip of land between the western border of the Kiefer property and another lot, which also extended to the shore of Blue Lake (the "Walk"), the Dillers extended a pier into Blue Lake. ${ }^{17}$ The Kiefers challenged the Dillers' authority to install a pier into Blue Lake off of the end of the Walk. ${ }^{18}$

"Neither the Dillers' Special Warranty Deed, nor Keifer's Warranty Deed, contain[ed] language conveying to them any interest in the 10 foot walk located to the west of Kiefer's Lot 5 or the shoreline of Blue Lake by fee title ownership or by easement." 19 Evidence of the subdivision's original platter's intent with respect to the Walk indicated that lots within the subdivision were to enjoy the same rights to the Walk. ${ }^{20}$ Accordingly, both "Kiefer, the Dillers[,] and likely every lot owner within [the subdivision] share[d] the same rights to use the Walk." 21

Under the Indiana Administrative Code, a temporary structure in the form of a pier may be placed without the need for a written license if, among other things, it is placed by a riparian owner. ${ }^{22}$ Accordingly, because the Dillers were not riparian owners by virtue of their ownership of Lot 47, the ALJ had to determine "whether the Dillers possess[ed] an interest in the Walk 'sufficient to establish the same legal standing as the owner of land, bound by a lake' in order to qualify as a 'riparian owner'.".23

The ALJ determined that " $[\mathrm{n}] \mathrm{o}$ evidence exist[ed] in the record to support a conclusion that the Dillers possess any greater interest in the Walk than the

to preserve the public trust and the rights of neighboring riparian owners, there ideally should be 10 feet of clearance on both sides (for a total of 20 feet) of the dividing line between riparian zones. At a minimum, a total of 10 feet is typically required that is clear of piers and moored boats, although the area may be used for loading and unloading boats and for active recreation."')

12. 15 CADDNAR 67 (2019).

13. Id.

14. Id. at 67-68.

15. Id. at 68 .

16. Id.

17. Id.

18. Id.

19. Id.

20. Id.

21. Id.

22. Id.; see also 312 Ind. AdMIN. CODE § 11-3-1(b)(1)-(9).

23. Kiefer, 15 CADDNAR at 68; see also 312 IND. ADMIN. CODE $§ 11-2-19$ (defining a "riparian owner"). 
interest enjoyed by any other lot owner in [the subdivision], including Kiefer."24 Further, "[a]n 'owner in common of an easement may not alter or use the land in such a manner as to render the easement appreciably less convenient and useful for other co-owners." "25 Applying this standard, the ALJ determined that

[w]ith the Walk's lateral limitation of 10 feet, the use of the shoreline attributed to the Walk by the Dillers for the placement and maintenance of a temporary pier for their exclusive use effectively prohibits every other co-owner of the easement from making any use of that shoreline area. Such an outcome is not consistent with the appropriate use of a nonexclusive easement. ${ }^{26}$

Accordingly, the Dillers were ultimately "enjoined from placing a pier, mooring watercraft[,] or maintaining other temporary structures from the shoreline of or within the waters of Blue Lake within the lateral limits of the Walk."27

\section{REGULATION CONCERNING THE CLASSIFICATION OF PROPERTY ADJACENT TO OR LOCATED WITHIN THE BOUNDARIES OF AN INDIANA PUBLIC FRESHWATER LAKE}

Indiana law also regulates the use of riparian property based upon its physical characteristics and its classification. This section highlights recent decisional law arising from the type of lake property involved.

Indiana Department of Natural Resources v. Prosser turned on whether the property at issue qualified as an "area of special concern" or as a "developed area" under the Indiana Administrative Code for purposes of a seawall permit. ${ }^{28}$ The factual issue in regards to making this determination was whether the dredging completed on the property in 1947 and 1948 "increased the total length of the shoreline around Lake Manitou."${ }^{, 29}$

On review, the Indiana Court of Appeals held that substantial evidence in the record supported the administrative law judge's finding that Prosser failed to prove the previous dredging of the lake lengthened the shoreline. ${ }^{30}$ Though Prosser had presented testimony that the dredging had straightened the shoreline, the Court held that the testimony did not support a finding that the dredging had lengthened the shoreline. ${ }^{31}$ The Court explained that "an originally uneven shoreline between two points, even if shifted slightly landward, would not

24. Kiefer, 15 CADDNAR at 68 .

25. Id. (internal citations omitted).

26. Id.

27. Id. at 69 .

28. Indiana Dep't of Nat. Res. v. Prosser, 132 N.E.3d 397, 401 (Ind. Ct. App. 2019); see also 312 Ind. Admin. CODE $\S 11-4-2(b)-(d)$ (2020).

29. Prosser, 132 N.E.3d at 401.

30. Id. at 402 .

31. Id. (emphasis added). 
necessarily be longer if it were also straightened in the process." ${ }^{.32}$ Accordingly, because the court determined that Prosser did not establish that the dredging increased the total length of the shoreline around Lake Manitou, Prosser's application was properly denied.

Bourdon v. DNR concerned the Petitioners' request to remove Eddy Lake, located in Marshall County, Indiana, from the Natural Resources Commission's listing of public freshwater lakes. ${ }^{33}$ "Eddy Lake is identified as a [public freshwater lake] by the [Natural Resources] Commission in a nonrule policy document identified as Information Bulletin \#61 (Seventh Amendment), 'Listing of Public Freshwater Lakes' (IB \#61), as required by Indiana Code [section] 1426-2-24." ${ }^{34}$ Petitioners owned approximately 70 percent of the Eddy Lake shoreline.

In the Petitioners' opinion, the remaining approximate $30 \%$ of the Eddy Lake shoreline not owned by them "is not suitable for access due to ... location, lack of parking, geography, depth of the water and/or nature of the shoreline." However, the Petitioners do not have the authority to control all access to Eddy Lake by members of the public. ${ }^{35}$

Accordingly, Petitioners "filed correspondence . . . with the Natural Resources Commission seeking 'the nonlisting of Eddy Lake as a public freshwater lake."'36

Indiana Code section 14-26-2-3 defines a public freshwater lake as "a lake that has been used by the public with the acquiescence of a riparian owner." Indiana Code section 14-26-2-1.5 defines a lake as follows:

Sec. 1.5. As used in this chapter, "lake" means a reasonably permanent body of water that:

(1) existed on March 12, 1947;

(2) is substantially at rest in a depression in the surface of the earth that is naturally created;

(3) is of natural origin or part of a watercourse, including a watercourse that has been dammed; and covers an area of at least five (5) acres within the shoreline and water line, including bays and coves. ${ }^{38}$

Here, the ALJ found that all four statutory criteria were met. Regarding the aforementioned criteria, the ALJ found " $[t]$ hat Eddy Lake may have been altered by marl mining does not negate the reasonable conclusion that Eddy Lake is of natural origin and exists within a natural depression in the earth as required by

32. Id.

33. Bourdon v. DNR, 15 CADDNAR 51, 51 (2019).

34. Id. at 52 .

35. Id.

36. Id. at 51. (internal shorthand omitted).

37. IND. CODE $§ 14-26-2-3$.

38. IND. CODE $\S 14-26-2-1.5$. 
Ind. Code $\S 14-26-2-1.5(2) .{ }^{, 39}$

Further, "[i]n order to be considered a [public freshwater lake, the] 'lake' must have been used by the public with the acquiescence of a riparian owner." 40 Here, the Petitioners acknowledged that their predecessor in title did acquiesce to the public's use of Eddy Lake. Further,

[u]nder the particular facts of this proceeding, there [were] other property owners who own[ed] portions of the Eddy Lake shoreline. Regardless of the Petitioners' belief that access through these properties presents a challenge or is inconvenient, the other property owners would be within their authority to allow or disallow the general public to utilize their private property for the purpose of accessing Eddy Lake. ${ }^{41}$

For these reasons, the ALJ determined that the Petitioners were "not in a proper position to seek the nonlisting of Eddy Lake as a [public freshwater lake]."

\section{DAMS}

"The Dam Safety Act gives the Indiana Department of Natural Resources jurisdiction over certain dams in, on, or along streams in Indiana to protect Hoosiers' lives and property." ${ }^{43}$ The next two cases address issues stemming from Notices of Violation issued under Indiana's Dam Safety Act.

Three questions related to dams under the Dam Safety Act were addressed in Moriarity v. Ind. Department of Natural Resources: First, did the Department of Natural Resources ("DNR") "properly exercise jurisdiction over the dam" at issue; "[s]econd, did the DNR present substantial evidence [which] support[s] its classification of the dam as a high-hazard dam"; and third, could "the Moriaritys modify their dam to remove it from DNR's future jurisdiction?" 44 The Indiana Supreme Court "answer[ed] each of these questions in the affirmative." ${ }^{45}$

The dam at issue in Moriarity was built during the 1990s in relation to a fairly large pond built on the Moriaritys' farm. "Their pond covered between thirty and forty acres and contained at least one hundred acre-feet of water, and parts of the dam holding back this water were taller than twenty feet." "[T] "The DNR asserted jurisdiction over the Moriaritys' dam after concluding it was in, on, or along a stream, [and] it then assigned a hazard classification to the dam based on the assessed risk to nearby people and property." 47 In the early 2000 s, "the DNR sought to have the Moriaritys correct what it considered 'significant safety

39. Bourdon, 15 CADDNAR at 53.

40. Id.; see also IND. CODE $§ 14-26-2-3$.

41. Bourdon, 15 CADDNAR at 53.

42. Id.

43. Moriarity v. Ind. Dep't of Nat. Res., 113 N.E.3d 614, 617 (Ind. 2019).

44. Id.

45. $I d$.

46. Id.

47. Id. at 620 . 
deficiencies' in the dam according to [the Dam Safety Act]." ${ }^{, 48}$ Accordingly, after not correcting the issues, the DNR issued a Notice of Violation to the Moriaritys, to which the Moriaritys petitioned for administrative review. After a hearing, the ALJ issued a nonfinal order generally in favor of the DNR. Upon the Moriarity's objection to the nonfinal order, the Natural Resources Commission held oral argument and thereafter issued a final order "largely along the same lines as the administrative law judge's nonfinal order." ${ }^{\prime 4}$ Upon judicial review, both the trial court and the Indiana court of appeals affirmed. The Indiana Supreme Court thereafter granted transfer.

The first issue the court considered was whether the DNR had jurisdiction over the Moriarity's dam based on its location allegedly in, on, or along a steam of Indiana. "The Dam Safety Act gives the DNR jurisdiction over dams 'in, on, or along the rivers, streams, and lakes of Indiana." 50 However, neither the legislature nor DNR have defined the word "stream" for purposes of the Dam Safety Act. ${ }^{51}$ When an agency interprets a statute it is tasked with enforcing, the court gives the agency's interpretation "great weight" and stops its analysis if that interpretation is reasonable. "Here, the DNR identified a stream as "flowing water through a defined channel' with neither size nor consistency of water flow being determinative of the presence of a stream." ${ }^{, 53}$ Because the court found that there was no indication that this definition was inconsistent with the Dam Safety Act and because the definition the DNR used was "consistent with the plain, ordinary, and usual meaning of the word stream, it [was] reasonable," and the Court would not move forward with any other proposed interpretation. ${ }^{54}$

Next, the Court considered the issue of whether the DNR presented substantial evidence supporting its classification of the Moriarity's dam as a highhazard dam. "As part of its supervisory duties under the Dam Safety Act, the DNR must assign a hazard classification-high, significant, or low-to each dam within its jurisdiction based on the risk posed to life and property in the event of an uncontrolled release from the dam." "T5 "The DNR classified the Moriarity's dam as high-hazard. ${ }^{" 56}$ A high-hazard dam is defined by the Dam Safety Act as "[a] structure the failure of which may cause the loss of life and serious damage to homes, industrial and commercial buildings, public utilities, major highways, or railroads. ${ }^{57}$ The DNR presented testimony of two of its employees to support its high-hazard assessment. This testimony established that "the presence of a church, a home, and a road below the dam made it 'visually obvious' that it

48. Id. at $617-18$.

49. Id. at 618 .

50. Id. at 620 (quoting IND. CODE $§ 14-27-7.5-8(\mathrm{a})(1)$ ).

51. Id.

52. Id. at 621 (citing West v. Office of Ind. Sec'y of State, 54 N.E.3d 349, 353 (Ind. 2016)).

53. Id. at 621 .

54. Id.

55. Id. at 622 (citing IND. CODE $§ 14-27-7.5-8(\mathrm{~b})$ ).

56. Id.

57. IND. CODE $§ 14-27-7.5-8(b)(1)$. 
would likely be a high-hazard dam[]" and "if the dam broke above the house situated below the dam, it would cause "serious damage." ${ }^{58}$ Accordingly, based on this testimony, the Court found that substantial evidence supported the DNR's conclusion that the Moriarity's dam was a high-hazard structure. ${ }^{59}$

Finally, the Court considered the third issue: whether the Moriaritys could modify their dam to remove it from the DNR's jurisdiction. In short shrift, the Court held that the Moriaritys could in fact modify their dam to remove it from the DNR's jurisdiction from that point forward. The Court explained that the Moriaritys could do so by modifying the dam so that it no longer exceeds a height of twenty feet or impounded more than one hundred acre-feet of water (along with the other statutory requirements of Indiana Code section 14-27-7.5-1(1)).$^{60}$

Miami County, et al. v. DNR similarly considered Notices of Violation issued under the Dam Safety Act related to six dams situated in the Hidden Hills subdivision located in Peru, Miami County, Indiana. ${ }^{61}$ Miami County, the Miami County Board of Commissioners, and multiple persons holding fee title to property upon which each of the six dams were constructed were determined to be owners of the dams within the meaning of Indiana Code section 14-27-7.5-4. ${ }^{62}$ Miami County, et al. discusses the history of the Dam Safety Act. Specifically, the case examines the similarities between the current version of the Dam Safety Act and the prior version for purposes of retroactive application of the Act. ${ }^{63}$ Namely, the owners of the dam claimed that the dams were not under the regulatory control of the DNR and the Natural Resources Commission because they were constructed before the effective date of Indiana Code section 14-277.5. ${ }^{64}$ However, the ALJ found this contention without merit. ${ }^{65}$ Specifically, the ALJ found that

[w]hile certain provisions of Indiana Code $\S \S 14-27-7.5$ et seq. may impose new or different requirements upon dam owners or may have altered the manner in which the [DNR's] inspection and regulation of dams is carried out, the portions of Indiana Code $\S \S 14-27-7.5$ relevant to this proceeding are not significantly different from the regulatory control granted to the [DNR] and the [Natural Resources Commission] through the equivalent portions of predecessor statutes that were clearly in effect between 1990 and 1996 when the dams were constructed. ${ }^{66}$

For this reason, and because the DNR and Natural Resources Commission had routinely exercised regulatory control over dams before the enactment of Indiana

58. Moriarity, 113 N.E.3d at 623.

59. Id.

60. Id. at 623-24.

61. Miami Cty., et al. v. DNR, 15 CADDNAR 17, 17 (2018).

62. Id.; see also IND. CODE $§ 14-27-7.5-4$ (defining an owner of a dam).

63. Miami Cty., et al., 15 CADDNAR at 28-30.

64. Id. at 30 .

65. Id.

66. Id. 
Code section 14-27-7.5, the ALJ held that the dams were under the regulatory control of the DNR and the Natural Resources Commission, despite the fact that they were constructed before the effective date of Indiana Code section 14-27$7.5 .^{67}$

\section{CONCLUSION}

Each year, the substantial geologic and geographical character of the State of Indiana, with its hundreds of natural lakes and watersheds, creates opportunities for significant developments in Indiana's lake and water jurisprudence. This year was no different. We look forward to bringing you future developments in this vitally important area of law, which impacts the fiber and fabric of the Hoosier State and thousands of its residents who cherish the quality of life that our waters provide.

67. Id. 